\title{
Thinking about future/democracy: towards a political theory of futurity
}

\author{
Rosine Kelz ${ }^{1}$
}

Received: 30 August 2018 / Accepted: 15 April 2019 / Published online: 6 May 2019

(c) The Author(s) 2019

\begin{abstract}
Today, representative politics are often perceived as being primarily concerned with short-term goals. Moreover, the future appears to be pre-determined by economic or technological necessities. This 'closing' of the future, however, becomes increasingly problematic in the face of global existential crises, such as environmental depletion and climate change. These catastrophic developments could only be mitigated by immediate, decisive political interventions, which would amount to systemic changes that redirect technological research and economic activities. This article seeks to outline how political theory and philosophy can contribute to "(re-)Politicizing the Future". I argue that political thought should take temporality, and in particular futurity, as a central conceptual and methodological concern. Drawing on the works of prominent twentieth century thinkers such as Hannah Arendt, Stanley Cavell, and Jacques Derrida, I want to develop a deepened analytical understanding of the possibility for a 'future directed' political thought which highlights intrinsic connections between sustainability and democracy.
\end{abstract}

Keywords Contingency $\cdot$ History $\cdot$ Futurity $\cdot$ "Democracy to Come" $\cdot$ Derrida $\cdot$ Cavell

\section{Introduction}

Politics is concerned with the future-this seems to be too obvious to need stating. Whether in debates about the building of a new road, the overhaul of national pension systems, or the forging of transnational agreements on climate change mitigation, all these disparate forms of political decisionmaking carry implicit or explicit visions of preferable futures. For many, however, this truism sounds increasingly hollow. It appears as if representative politics in contemporary liberal-capitalist countries is concerned primarily with short-term goals. Even social movements are often criticized for lacking positive visions of a future that would radically differ from the current status-quo. Western societies seem to have lost their abilities to imagine utopian futures

Handled by Anne-Katrin Holfelder, Institute for Advanced Sustainability Studies, Germany.

Rosine Kelz

rosine.kelz@iass-potsdam.de

1 Institute for Advanced Sustainability Studies E.V (IASS), Berliner Str. 130, 14467 Potsdam, Germany
(Habermas 1985: 7). The disappearance of possible futures that would be profoundly different from the present has been propagated as both a political reality and a normative standpoint since at least the early 1980s, and is often linked to the rise of neoliberal forms of government (see, e.g., Fukuyama 1992; Séville 2017). From Margaret Thatcher's famous proclamation that 'There is no Alternative' to current austerity reforms, the political future is presented as pre-determined by economic or technological necessities. This 'closing' of the future at first sight would seem to be at odds with the obvious acceleration of late modern societies, where things appear to be in constant flux. However, while acceleration and rapid change are often regarded as hallmarks of modernity, these are highly uneven and aporetic processes. Some theorists argue that the acceleration of other parts of society leads to a 'hyper-accelerated standstill' or to 'polar inertia' in the political sphere (see, e.g., Rosa 2003: 17, 21). In the face of rapid movements and shifts in areas such as financial markets or scientific research, representative democratic politics appears to have lost the ability to actively steer social developments. The need for future directed political action and thinking, however, becomes ever more pressing. From the extraction of fossil fuels and the use of nuclear power 
to genome editing - the use of contemporary technologies has consequences which stretch far into the future. At the same time, capacities for modeling and thus anticipating the possible effects of actions on a global scale have increased rapidly in the past decades. We are currently confronted with dystopian scenarios of environmental depletion and a rapidly changing climate, but current liberal democratic governments often seem to lack the political will to implement systemic changes that would make it possible to avoid the most disastrous pathways.

Even though there is thus an obvious need to theorize how politics relates to the creation of future(s), current political theory often appears strangely uninterested in the temporal character of the political sphere. What is called for, then, is political thought that contributes to a project of actively (re-)politicizing societal and political notions of the future. As the 'Politicizing the Future' project members argue, this would involve a number of diverse practices which enable the proliferation of multiple alternative possible futures in the present. These practices are intrinsically linked to the pluralization and deepening of democratic processes. However, even though one explicit normative goal of this project is to 'open up' the realm of thinkable futures, not all visions of future are equally valued. The normative dimension also entails a notion of strong sustainability, allowing for future generations to exist in a world with a livable natural and just social environment. Thus, Politicizing the Future involves a 'de-colonization' of the future, where present people have to refrain from using up resources and creating ecological and socio-political issues that would disadvantage those who come after them (Knappe et al. 2018, this issue). The aim of this article is, therefore, twofold. First, I want to show that there are resources in political and moral thought to highlight the importance of temporality and futurity, which can be useful for current debates in sustainability studies. Second, this paper seeks to further explore the normative connections between futurity, democracy, and sustainability, which are proposed by the members of the 'Politicizing the Future' project.

The notion of (political) contingency is an excellent starting point to explore the connections between a commitment to an open future and the concept of democracy. By political contingency, I mean the simple fact that even though the way a society is organized is not random, it could always be otherwise (Marchart 2010: 80). As political systems are created by overlapping processes, whose beginnings cannot be clearly determined and whose developments do not follow necessary pathways, contingency is a feature of any form of societal organization. However, many forms of rule disavow their own contingency. Often, they seek to affirm their own necessity and immutability by appealing to something outside of the realm of politics, as, for example, a doctrine of divine right, or the unyielding laws of the market. By contrast, the idea of democracy presupposes its own contingent political foundation. Making contingency explicit, in turn, allows for a continuous renegotiation of possible futures. Moreover, as I will discuss in Section I, affirming contingency entails a specific relationship to the past-and to the role of history in understanding the present and the future- that enables us to learn from past events without understanding history as determining the future. Section II concentrates on the notion that the concept of democracy is closely linked to a particular understanding of futurity. A democratic commitment to an open future, in turn, also implies a commitment to at least a "thin" notion of sustainability. In Section III, the relationship between democracy and sustainability is explored further. I argue that while a societal turn to more sustainable social and economic practices would involve the willingness of individuals to make substantive changes in their daily lives, these commitments are political in nature. Instead of sliding into a neoliberal logic of individualized 'sustainable consumption', what is called for is an understanding of moral autonomy that involves a deepening of shared, democratic practices.

\section{Against linear time? History, teleology, and the closing of the future}

In the grand philosophical systems of the European Enlightenment the future plays an important role. With modernity, a notion of history emerged that sought to encompass the whole of humanity's existence into one cohesive narrative of universal progress-from the ancient past to an endpoint in the future (Koselleck 2002). Building on the eschatological tradition in Western thought, early modern philosophers start to understand history as "the fulfillment of a telos that one can rationally anticipate in advance in the form of an idea". Humankind then either has to "hope to approximate" this idea, as in Kantian teleology, or "work towards actualizing" it, as in Hegelian-Marxist teleology (Cheah and Guerlac 2009: 15). In both systems, it is imagined that humans develop towards an increasingly rational state by accumulating knowledge and understanding. This, in turn, allows for individual and societal emancipation. For Kant, for example, it is an "inborn duty" to influence "posterity in such a way that it will make constant progress" (Kant 1991b: 88-89). As Kant explains elsewhere "It will require a long, perhaps incalculable series of generations, each passing its enlightenment to the next, before the germs implanted by nature in our species can be developed to that degree which corresponds to nature's original intention. In addition, the point of time at which this degree of development is reached must be the goal of man's aspiration ... or else his natural capacities would necessarily appear by and large to 
be purposeless and wasted" (Kant 1991a: 43). The linear historical progress of humankind is presented here at the same time as the unfolding of a natural capacity and as necessitating active human engagement. The latter is a moral duty, because it is intended by nature. For Kant, we not only have an obvious 'natural' responsibility for future generations, the way in which future generations should develop can already be known in the present.

In the course of the twentieth century, however, the idea of progress and the notion that one can deduce the future from an analysis of history has become increasingly suspect. On the one hand, progress appeared to be palpable in the rapid development of science and industry. On the other hand, however, these transformations were often experienced as deeply disruptive and unpredictable. In addition, in the light of struggles against (neo-)colonial rule, the ingrained Eurocentrism of Western notions of progress started to become more widely recognized (see e.g., Allen 2016). Attempts to provide a single, encompassing narrative of humankind's development had failed to acknowledge that economic growth in Europe had depended on colonial expansion. Europe has externalized many social and ecological 'costs' of industrial growth into other world regions (Chakrabarty, 2012). Not only did universalistic theories not fully account for the massive oppression, violence, and destruction that accompanied European 'modernization', Eurocentric ideas of progress themselves have been recognized to be at least partly responsible for the rise of imperialism, totalitarianism, and environmental depletion. In the wake of two catastrophic World Wars and the Holocaust, however, the notion of continuous linear progress started to sound hollow even within Western societies. As Adorno famously wrote, Auschwitz "makes all talk of progress towards freedom seem ludicrous" (Adorno 2006: 7).

Hannah Arendt is one of the best known among the European political thinkers who were led by the shocks of the first half of the twentieth century to re-evaluate notions of causality and history in political philosophy. She criticizes that political philosophy has disregarded the importance of singular actors and events. For her, this sentiment cumulated in Marx's Hegelian understanding of history. Marx, as Arendt reads him, retains a 'Platonic' hostility towards human affairs and particularity, because he bestows importance and dignity not on the acts of individuals but "upon mere time-sequence" (Arendt 2006a: 65). For Arendt, then, a teleological understanding of history is linked to an inability to understand oneself as a singular actor, capable of bringing about unexpected events, and thus radical political change. This had devastating consequences in the early twentieth century, where people considered themselves as mere 'cogs in the machine', with no personal responsibility for the 'progress' of historical forces (Arendt 2006b: 25-26). The consequence of this mindset is not only political quietism; it can also allow people to reject their moral responsibility for the roles they play in totalitarian regimes.

In the wake of the catastrophes of totalitarianism, Arendt argues, history can no longer be understood in a linear manner. We are left with "a fragmented past, which has lost its certainty of evaluation" (Arendt 1978: 212). This fragmentation, together with a critique of teleology, however, can lead us to a productive re-evaluation of the concept of history. To do so, Arendt refers back to Greek and Roman notions of history which, in her understanding, retain causality and context, but find them within the "light provided by the event itself, illuminating a specific segment of human affairs". Contrary to the modern view of history, there is no independent existence of causality and meaning "of which the event would be only the more or less accidental though adequate expression" (Arendt 2006a: 64). As Reinhart Koselleck explains, Ancient Greek and Roman notions of relative progression are always restricted to specific areas. These partial, local notions of 'progress' are established by looking back on past developments, but do not make it possible to predict the future (Koselleck 2002: 221). Such an understanding of history, Arendt maintains, can loosen the power the past holds over political actors while retaining historical stories and events as shared reference points and examples for political discourse. This is important, because political action, for Arendt, has to be inspired by and directed towards a shared, human-made world, and stories of the past make up an important part of this shared frame of reference. While political imagination and action thus remain guided by examples from the past, they are freed from historical necessity.

Engaging with the past without seeking to extrapolate a unified narrative of historical progress also makes it possible to explore past events from different perspectives. This includes the stories of people who were colonized or enslaved, who suffered from oppression and violence. Their experiences often could not be articulated and preserved within the progressive framework. It can also entail unearthing the hopes and possibilities suggested in moments of upheaval or revolt which did not come to fruition. While such practices of re-appropriating the past need to be careful not to slide into revisionism, they can help to highlight that even though the present is not arbitrary, it is contingent. Things could have been otherwise- there were avenues not taken, and possibilities not fully explored. Importantly, I do not suggest that we abandon a 'realist' intuition about the past. There are knowable historical facts. However, we have to acknowledge that because the world is infinitely complex, any human interpretation will only ever capture a partial, particular perspective of any event (Hoy 2012: 99-100). To stress that our understanding of the past is partial and that things did not necessarily have to develop the way that they turned out, might also make it easier to acknowledge the 
complexity and contingency of our current economic, social, and political status-quo. This is important for an understanding of democracy which takes the Greek notion of doxa, as the possibility of different viewpoints or opinions that equally hold truth, seriously. Democratic politics involves an understanding that there can be not one, single correct understanding of the human world. As Cornelius Castoriadis phrases it, "[i]f a full and certain knowledge (episteme) of the human domain were possible, politics would immediately come to an end, and democracy would be both impossible and absurd: democracy implies that all citizens have the possibility of attaining a correct doxa and that nobody possesses an episteme of things political" (Castoriadis 1997: 274).

While at first sight, it might seem counterintuitive to begin an article devoted to "Politicizing the Future" with a discussion of concepts of history and a critique of progress, this section hopefully has shown that by rethinking these notions, we can move from a pre-determined to an open future. In the next section, I will concentrate more concretely on establishing a link between futurity and the concept of democracy - thus strengthening the connection between an understanding of future(s) as open and multiple and a normative commitment to democracy.

\section{Democracy as futurity}

There are many, often mutually exclusive, notions of what 'democracy' entails. This openness is an essential aspect of democracy. To stay democratic, democracies need to remain unable to find conceptual, legal, and institutional closure. One reason for this is that democracies, like any other form of political regime, exist in specific points in space and time, under specific 'material' circumstances. While governments can, to an extent, steer how natural resources are used or which technologies are developed, while they can decide how to prepare for and react to natural disasters such as droughts or earthquakes, these forces also shape social and political relations. In short, with differing historical, cultural, and material circumstances, different forms of democracy emerge. For example, as Timothy Mitchell argues, industrialized liberal democracies of the second half of the twentieth century relied heavily on fossil fuels, in particular oil. The availability of cheap energy altered living standards for large proportions of the population in the global north. Fossil fuel extraction industries played an important role in the development of labor relations, and influenced the forms in which relevant sectors of the working class and industry organized politically and were represented in government (Mitchell 2009). Moreover, reliance on fossil fuels has had profound impacts on international politics, which in turn has also shaped contemporary notions of the role of liberal democratic regimes in the global system of nation states. Today, liberal representative democracies seem to struggle with adapting to the reality of anthropogenic climate change. One could interpret these difficulties as an inability of contemporary forms of political representation to come to terms with changing environmental realities. In this sense, calls for a transformations to more environmentally sustainable forms of energy production and consumption can also be taken as an occasion for the 'democratization' of contemporary democratic regimes.

In the context of recent ecological crises, caused among other factors by the reliance of fossil fuels, the question of how democracies could better engage with the 'non-human' world has regained traction in political theory. Current challenges to a traditionally anthropocentric understanding of democracy raise the question of whether non-human beings, things, and relatively abstract entities such as "nature" need to be able to hold rights or be otherwise represented in democratic regimes, and how this could be best accomplished (see, e.g., Bennett 2010; Povinelli 2016; Derrida 2008). Questions about who can belong to the community of citizens, and whose voices and needs should be represented, are not new, however. Liberal representative governments have repeatedly faced challenges to their definitions of membership and their (territorial) boundaries. Here, examples from the past, such as the movement for women's right to vote, might come to mind. Or, we could think of ongoing debates about migration, where the rights of people to enter state territories and possible paths to citizenship have become issues of fierce political contestation. As 'empirically existing' regimes never rest on firm foundations, such questions cannot be ultimately settled, and thus any democratic community needs to remain open to future challenges to their definitions of membership. This, however, brings an unresolvable question to the fore which lies at the heart of the concept of democracy: are we in political community with those who are most similar to 'us', or should political community be sought with those who are (maybe radically) different? As Jacques Derrida (2005a) seeks to retrace in his book on the "Politics of Friendship", a logic of political friendship as fraternity has been long inscribed in the notion of politics in the Western tradition. In his reading, this also links understandings of political community and citizenship to notions of autochthony or (genetic) sameness, where a connection is drawn between 'blood', land and nation (Derrida 2005a: 106). The creation of a homogenous 'we', however, relies on the construction of external and internal 'others' against whom community needs to be defended. This logic is deeply inscribed within today's system of liberal democratic nation states. For Derrida, however, it is not in keeping with both the 'promise' of 
the concept of democracy, and the realities of today's globalized world. ${ }^{1}$ There is also a second, related form in which Derrida discusses the issue of homogenization as an irresolvable issue within political communities. Democracy cannot exist without "the calculation of majorities, without identifiable, stabilizable, representable subjects, all equal" (Derrida 2005a: 22). This threatens the possibility to see the singularity of each being-and there can also be no democracy "without respect for irreducible singularity or alterity". "These two laws", Derrida writes "are irreducible one to the other. Tragically irreconcilable and forever wounding" (Derrida 2005a: 22). A political need to 'count' and to homogenize is thus confronted with the ethical necessity to respect alterity and to leave the political community open to the arrival of 'others'. From these irreducible aporiae, however, "political desire" arises. Democracy's necessary "inadequacy to itself" is what keeps the political realm alive, because it calls for continuous contestation (Derrida 2005a: 22).

With his phrase 'democracy to come' Derrida seeks to express the integral connection between the concept of democracy and futurity. It expresses not only the necessity for constant renegotiation, but also the possibility of radical change. Not despite but because of the tensions inherent in its conceptual history, Derrida understands democracy as an (unfulfillable) promise. Inscribed in the concept of democracy is the belief in an endless process of perfectibility. While this implies that the actual 'arrival' of a 'perfect' democracy needs to remain impossible, it also means that the promise entails an injunction for action in the present. Such a perfectionist understanding of democracy remains close to (Kantian) teleology. Derrida, however, seeks to avoid a strong understanding of teleology by insisting on the radical openness of the future. Because a 'real' future remains unknowable and incalculable, democracy as a 'regulative ideal' also needs to remain underdetermined. However, Derrida does not leave his understanding of 'democracy to come' entirely open. Because of the importance of alterity and difference and the ethical responsibility towards excluded 'others', which is neglected in current liberal democratic regimes, the sphere of democracy needs to be broadened beyond "classical' modern notions of nation, state and citizenship. Democracy, then, is better understood as a practice that can arise in various socio-political arenas, where one can encounter others under the heading of equality, justice, equity and respect.

Derrida is well aware that democracy's necessary openness to dissenting voices and 'newcomers' can be dangerous. The notion that democracy is "self-criticizable" entails that in a democratic regime, the very value of democracy

\footnotetext{
${ }^{1}$ Arguably, European societies have never possessed a great level of internal cultural and linguistic homogeneity, despite modern efforts to create more homogeneous peoples in the process of 'nation-building'. Hobsbawm (1992).
}

can be called into question (Derrida 2005b: 22, 24-25, 87). However, Derrida is somewhat ambiguous on how democracies should deal with the danger of non-democratic challengers. He states, for example, that while " $[t]$ he coming of the event is what cannot and should not be prevented", because "it is another name for the future itself", this "does not mean that it is good-good in itself-for everything and anything to arrive". One should try to prevent those things from coming to pass "that one thinks will block the future or that bring death with them: events that would put an end to the possibility of the event" (Derrida 2002: 194). That we should try to prevent something from coming to pass, however, does not mean that it can be ruled out. Indeed, it is the ever looming possibility of a catastrophic ending that makes continuous political engagement necessary. One is driven to participate in politics, not only because one could always 'better' democracy, and renegotiate compromises inherent in the tenuous nature of democratic communitythe very aliveness of democratic politics is also fueled by the possibility of its destruction. If future is really understood as open, as that what cannot be known in advance, what 'comes' to us, but is not determined or planned by us, then future can never be 'safe'. As Derrida writes in his early text Of Grammatology, "[t]he future can only be anticipated in the form of an absolute danger. It is that which breaks absolutely with constituted normality and can only announce, present itself as a kind of monstrosity" (Derrida 1974: 14).

It is in such reminders of possible disastrous futures that I understand 'democracy to come' to also involve an appeal for at least a 'thin' commitment to sustainability. Like 'democracy', 'sustainability' is a notoriously underdetermined concept. 'Sustainability' might be better understood as a discourse, where competing definitions are negotiated. Originally, the term 'sustainability' had an explicitly economic connotation, and was used to describe practices that would not use up a (natural) resource (e.g., a forest), but use it in a way, where it can replenish, and thus be conserved for future use (Muraca 2010: 25). In recent, broader definitions, however, notions of sustainability include issues of social justice and normative arguments for ecological conservation as a good in itself. In these formulations, a possible overlap with the notion of 'democracy to come' becomes apparent. Both concepts are related to an open future, where as many pathways as possible need to be held open. By fostering diversity (of forms of life, of ecosystems, of cultures, of languages) today, sustainable practices seek to enable a multiplicity of possible futures for a multiplicity of living beings. ${ }^{2}$ With 'thin' sustainability, then, I do

\footnotetext{
2 For a detailed discussion of the connection between sustainability, diversity, and Derrida's thought, see, for example, Lynes (2018).
} 
not mean a purely 'economic' definition of sustainability, but that the precise content of what sustainable practices amount to cannot be spelled out a priori, because this has to be open to negotiation in the democratic political sphere. However, paradoxically, for this to be possible, some conditions of sustainability also need to be met. This includes an understanding of sustainability as social justice, because, as Arendt forcefully argues in On Revolution (1963), a functioning democratic political sphere needs at least a minimum of economic and social equality, so that everybody is able to engage in politics with the common good in mind.

While I ended section I by pointing out that democracy needs to allow for a variety of diverging view points to exist about the "world", in this section, I made the argument that democracies also need to acknowledge that there are different justified opinions about what democracy itself should entail. This openness interweaves the notion of democracy with the notion of futurity. Democracy has the structure of a promise, of its own perfectibility, whose 'content' needs to remain 'open', because of the complexity of competing demands and the incalculability of the future. In my understanding, a 'futural' notion of democracy highlights the inherent connection between democracy and at least a 'thin' conception of sustainability. If the realm of democracy needs to be constantly rethought, and broadened beyond the level of representative liberal nation states, however, we have to ask how democratic practices can take form in our daily lives. In the final section, I therefore turn my attention to the role of personal agency.

\section{Cavell's moral perfectionism, agency, and democratic sustainability}

So far, we have investigated the connections between futurity, democracy, and sustainability by looking more closely at notions of democracy and temporality. If, however, unexpected events are brought into being not by 'mere timesequence', but by complex interactions between singular actors, we also have to consider what motivates people to become active in the political realm. Such motivations, I argue, are often rooted within one's personal 'moral' concerns and beliefs. I take sustainability here as one of the possible ethical concerns that can motivate political engagement. At the same time, sustainability can also be understood as a democratic practice in itself. To make this argument, I turn from Derrida's notion of 'democracy to come' as a perfectionist understanding of democracy to Stanley Cavell's discussion of the perfectionist moral self. Traditionally, moral perfectionism is based on an idea of the 'good', which can be used to orientate our actions. In Cavell's understanding, however, perfectionism involves the cultivation of the self. While this activity is future oriented and aims at allowing the self to become more autonomous, it otherwise leaves the content of the 'good' relatively open. In this context, autonomy connotes the ability to assume a position from which current societal norms can be critically assessed, and one's own unique stance in relation with these norms can be formulated. At the same time, however, personal autonomy can only be understood within the context of the deeply relational character of our existence. When we approach the role of singular persons in bringing about more sustainable every-day practices, it is, therefore, important to avoid falling into a 'neoliberal' rhetoric of self-responsibility that disregards social constraints and dependencies. For example, the decision whether I drive to work by car, ride my bike, or use public transport can be framed in terms of autonomous decision-making-I decide for myself in accordance with my individual beliefs and needs which type of transportation I prefer. By extension, this can imply that the problem of car exhaust pollution comes down to the decisions of individuals and it is thus up to each of them alone to bring about cleaner air. Societal norms and narratives, however, link my private transportation choices to broader notions of social identity or economic status and can even make them into visible signs of my political affiliations. Instead of making my decision about transportation in isolation, I am well aware of the opinions of my partner, friends and colleagues, and their understanding of an acceptable choice will influence mine, even though I might not always be aware of this. When we start our inquiry from the perspective of the acting individual, then, this still needs to involve that we understand individuals as socially embedded.

These interactions between one's relationship to others and one's understanding of self are topics Stanley Cavell seeks to explore in his engagements with ordinary language philosophy and perfectionist moral thought. Ordinary language philosophers maintain that the meaning of words is not established via a connection between a word and an object in the external world directly, but via the agreement between the speakers of a language. This necessarily situates a speaker within a social world, shared with other speakers. Communication and agreement with others become the contingent ground of meaning (Cavell 1976: 50). Learning a language, then, involves understanding how other speakers use specific concepts in context. If learning how words are used by others was all there was to learning a language; however, language would be static, and thus unable to grasp the ever-changing world. Instead, Cavell argues that personal agency plays an important role in the functioning of language. Speakers can only be said to have fully grasped the meaning of a concept if they are able to use it creatively-in a new setting, for example. By applying concepts in different ways or in new circumstances, every speaker can take part in the evolution of language. Using words creatively, speakers also reveal something about themselves-they show their 
individuality. However, when a speaker makes a creative projection, there is no guarantee that others will understand or accept their novel use of the familiar concept. If understanding fails, the limits of one's agreement with others are revealed-and this can be threatening to the self. We need others, not only for our very physical survival, but also to make sense of the world. Accepting and allowing for one's dependency and vulnerability, however, make it possible to more deeply grasp the relational aspect of one's existence. This, for Cavell, is an important aspect of developing one's moral agency. However, because there are risks involved in challenging (linguistic or social) convention, Cavell argues that this kind of agency has to be actively chosen. Yet, failing to do so would not only ossify society, it would also rob one of the opportunity to 'get to know' oneself better and thus become a more autonomous self.

Cavell develops his notion of selfhood by engaging with the idea of moral perfectionism. His version of perfectionism is linked to a notion of futurity similar to Derrida's. For Cavell, leading a good, moral life entails continuous work to better understand or know oneself and one's situatedness in the social world. A "moral creature" is, therefore, one "that demands and recognizes the intelligibility of others to himself or herself, and of himself or herself to others" (Cavell 1990: xxxi). The wish to become intelligible or to 'define' one's own stance in relation with one's community often arises when one finds oneself in a situation, where one can no longer agree with some of the core practices or norms of one's society. For example, a person could realize that accepted definitions of concepts such as sustainability or democracy do not fit with her society's actual practices and that she cannot accept this discrepancy. Or maybe, she feels that the conventional definition of democracy is not fully able to express her own understanding of what 'real democracy' would entail. Such experiences can lead to a sense of estrangement, not only from one's community, but also from oneself. There might be "a sense of disappointment or dissatisfaction with oneself, one's language, and one's relationships with others". This might be experienced as "a feeling of aversion" towards oneself and/or others, where a person feels the others can no longer speak for her, or she for them (Flathman 2006: 103-104). Overcoming this estrangement, Cavell argues, is an endeavor that links an attempt to know and develop one's own sense of self together with finding one's political voice. Cavell's notion of political voice draws on Rousseau, who distinguishes between the private will and the general will. The private will expresses desires an individual has 'for herself' - it is not necessarily connected to her membership in a community. This will, Rousseau argued, often fueled by basic desires or 'appetites' such as hunger or lust, and has usually not been examined closely. By contrast, the general will enable us "to speak for one another", and thus form a democratic political community.
The general will "is an autonomous will, one that is at once subject and object to itself and, as such, one that allows for the reflective activity of self-appraisal and self-interpretation" (Norris 2017: 106 my emphasis). Importantly, for Rousseau, it is possible that an aggregate of private wills is mistaken for the general will of a community. Then, even though a majority agrees on this point, their wills do not actually express what would be good for the community as a whole. In Cavell's work, this notion of a shared general will, where one assumes to speak for others, become closely linked to the agreement between speakers that is necessary for conversation. As Andrew Norris explains "[n]either the linguistic nor the political community are ... aggregations of discrete individual choices all the way down. For us to speak the same language or to stand in a distinctively political relationship with one another we must, ... feel or respond together, be in intimate attunement with one another" (Norris 2017: 116). To develop one's political voice, then, is also a quest to find out if, or in how far, one can speak for others-it is a claim to community.

There is a futural aspect to Cavell's interlacing of moral and political thought. When finding herself estranged from herself and her community, a person, turning to perfectionist ethics, imagines a possible better future self and the community that would need to exist for such a self to be possible. The possibility to imagine a better future self then sets in motion a process of transformation, in which not only the 'current' self changes, but also the imagined future self. This is the case, because the perspective on what a 'better' self would entail develops as the person gets to 'know' herself and her relationship to her community better. Importantly, for Cavell, just as one can never know everything about the world or about another person, one can also never fully 'know' oneself. The perfectionist quest of 'getting to know oneself' thus cannot come to an end. In this understanding, the very temporality of selfhood is highlighted. The self becomes rethought as an open-ended process of discovery and re-articulation, not as a fixed identity. Similar to Derrida's understanding of 'democracy to come', Cavell's perfectionist future self, therefore, needs to remain without 'content'. Nevertheless, Cavell also offers some ideas about how perfectionist moral thought that takes our reliance on the natural and social environment seriously could proceed. In the context of an essay on animals, he draws on Thoreau to give voice to the perception that the very "assertion of the will to live in the world", which requires 'feeding' oneself (both in a metaphorical and a literal sense) is "without certain justification". Living in Walden, Thoreau experiences that "there are debts in living, conditions of existence, uses to which he puts, or fails to put, the peaceable space cleared for him before he cleared it, that are uncountable. What makes them insupportable is the degree to which they are unnecessary. Then, the quest in which an adventurous life 
may well be spent in search, or experiment, is to replace false by true necessaries, or means, to what one truly finds good (a quest as ancient as Plato's Republic)"(Cavell 2008: 117). For Cavell, Thoreau's point is that a sense of debt, resulting from the injury one causes others, is an irreducible part of human existence. To meet one's bodily needs, one always uses some natural resources and is implicated in the killing of living beings. Moreover, in contemporary societies, one often depends on the labor of others to fulfil one's own needs and desires. While to an extent this cannot be helped, we need to ask ourselves, Cavell argues, what we truly need, and where we might be involved in the killing or exploitation of others to satisfy desires that are not essential to our existence. Moreover, the question of 'true needs' always also involves the question of justice, where it appears unjustifiable that some human beings would require so much more resources than others. However, to define what is 'essential' for one's life, Cavell cautions, is not a straightforward or simple task.

This reading of Thoreau is reminiscent of degrowth positions within the sustainability discourse, which have focused on overcoming a logic of economic growth, decoupled from need or necessity (see e.g. Asara et al. 2015). They criticize the prevalence of the progressive narrative of the expansive market, which retains the idea of a colonizable world. Many proponents of 'degrowth' argue that it is necessary to 're-politicize' the sustainability debate. This involves questioning the notion of 'the market' as an unconditional ontological ground, not only for the political, but also for the individual. The 'neoliberal' market logic at the same time overstates and understates the role of the individual. By postulating a sovereign, self-interested subject, it excludes the role of social relationships and structural constraints on individual decision-making processes. At the same time, it understates the ability of individuals to arrive at a systemic critique of socio-economic structures and bring about substantial change via political action. By opening political spaces in which the "naturalization of the need of economic growth and capitalism as the only reasonable and possible form of organization of socionatural metabolism" can be criticized, then, the degrowth movement maintains that other forms of political, social and economic organization of societies can be developed (Swyngedouw 2014: 91). As I understand it, the idea of true needs and the notion of degrowth are critical of Eurocentric notions of progress, without necessarily seeking to establish an ethos of austerity. Instead of having 'less' for everyone, what is aspired to is a 'more' in diversity, where different kinds of lives are encouraged to flourish (not only those useable for the capitalist market), and diverse and new forms of living together, of engaging politically and economically, are explored. Asking what we 'truly' need, and where our consumption habits go at the expense of others, also includes a critical engagement with the current norms of our societies. In a highly industrialized, globalized world, where our daily actions have effects on a variety of living beings, on ecosystems and climate patters, over large time spans and across continents, however, it also means that the question of who belongs to 'our' community has to be re-posed.

\section{Conclusion}

When we try to imagine different, better futures, and ways to get there, we cannot proceed as if from a tabula rasa. The inheritance of European modernity include notions of justice, freedom, and democracy on which ideas of the future can build, governmental institutions, and economic systems with which we have to reckon, as well as deeply rooted histories of colonization, imperialism, social and ecological exploitation, and structural injustice which we have to address. While it is important to highlight how forms of inequality, oppression and discrimination are institutionalized and have shaped our material environment, a critical and open engagement with the past and present forms of violence should also acknowledge the contingency of the present. Things could have been otherwise, and thus can be different in the future. Embracing contingency also involves interrogating one's own stance towards the communities one is a part of, often without one's own choosing. As Cavell reminds us, even if we were utterly dismayed with the current practices and believes of the society we live in, we cannot simply 'wash our hands off it'. A life lived and understood completely independent of others must remain an illusion. Cavell argues that we cannot 'opt out' of our relationships with others, without taking the risk of losing our connection to the world and thus also to ourselves as agents in the world. As relational beings we have to engage with the situation in which we find ourselves. We, therefore, have to interrogate our stance towards our society and seek to discover a shared political voice. This might also involve the rethinking of what we understand as democratic practices and the 're-politization' of areas of society that are currently seen as outside the realm of democratic decisionmaking. Not only are we always already members of social or political groups, however, any community is also always somewhat open to its outside. Derrida's approach emphasizes that the boundaries of one's community have to remain contestable. To engage with the ways, political categories and boundaries have been historically constructed, enable us to highlight their contingency, and open up and rethink current concepts of membership and representation. Accepting the permeability of social structures, their necessary openness to newcomers, including future generations, allows us to imagine democratic politics in a more open fashion. The technologically extended temporal and spatial reach of our 
actions today might make it necessary to reconsider what justice and democracy could mean in relation to those who come after us. We have to ask how we can account for the fact that the political decisions (and 'private' consumptionpatterns) of a small privileged group of people have negative effects that disproportionally affect those who are not, or only marginally, involved in decision-making processes and who do not, or only marginally, take part in current problematic patterns of consumption-like many people living in the global south today, most non-human life forms, and future generations. Refiguring notions of political responsibility in this light is what I understand as an ongoing task of a 'futurized' political theory.

Open Access This article is distributed under the terms of the Creative Commons Attribution 4.0 International License (http://creativeco mmons.org/licenses/by/4.0/), which permits unrestricted use, distribution, and reproduction in any medium, provided you give appropriate credit to the original author(s) and the source, provide a link to the Creative Commons license, and indicate if changes were made.

\section{References}

Adorno T (2006) History and freedom: lectures 1964-1965. Polity, Cambridge

Allen A (2016) The end of progress. Decolonizing the normative foundations of critical theory. Columbia University Press, New York

Arendt H (1963) On revolution. Viking Press, New York

Arendt H (1978) The life of the mind. Harcourt Brace Jovanovich, New York

Arendt H (2006) The concept of history. Between past and future. Penguin, New York

Asara V, Otero I, Demaria F et al (2015) Socially sustainable degrowth as a social-ecological transformation: repoliticizing sustainability. Sustainab Sci 10:375-384

Bennett J (2010) Vibrant matter. A political ecology of things.Duke University Press, Durham and London

Castoriadis C (1997) The castoriadis reader. Blackwell Publishers, Oxford

Cavell S (1990) Conditions handsome and unhandsome: the constitution of emersonian perfectionism. University of Chicago Press, Chicago

Cavell S (2008) Companionable thinking. Columbia University Press, New York

Cavell S (1976) Must we mean what we say? A book of essays. Cambridge University Press, Cambridge

Chakrabarty D (2012) Postcolonial studies and the challenge of climate change. New Literary History 43:1-18

Cheah P, Guerlac S (2009) Introduction: derrida and the time of the political. In: Cheah P, Guerlac S (eds) Derrida and the time of the political. Duke University Press, Durham and London
Derrida J (1974) Of grammatology. John Hopkins University Press, Baltimore

Derrida J (2002) Negotiations: interventions and interviews, 19712001. Stanford University Press, Stanford

Derrida J (2005) The politics of friendship. Verso, London and New York

Derrida J (2008) The animal that therefore I am. Fordham University Press, New York

Flathman R (2006) Perfectionism without perfection: cavell, montaigne, and the conditions of morals and politics. In: Norris A (ed) The claim to community. Essays on stanley cavell and political philosophy. Stanford University Press, Stanford, pp 98-127

Fukuyama F (1992) The end of history and the last man. Free Press, New York

Habermas J (1985) Die neue Unübersichtlichkeit. Suhrkamp, Frankfurt

Hobsbawm EJ (1992) Nation and Nationalism Since 1780. Cambridge University Press, Cambridge

Hoy DC (2012) The time of our lives. MIT Press, Cambridge and London

Kant I (1991a) Idea for a universal history with a cosmopolitan purpose. In: Reiss H (ed) Political writings. Cambridge University Press, Cambridge

Kant I (1991b) On the common saying: 'This may be true in theory, but it does not apply in practice'. In: Reiss H (ed) Political writings. Cambridge University Press, Cambridge

Knappe H, Holfelder A-K, Beer DL, Nanz P (2018) The politics of making and un-making (sustainable) futures. Sustain Sci 13(2):273-274

Koselleck R (2002) The practice of conceptual history: timing history. Stanford University Press, Spacing Concepts, Stanford

Lynes P (2018) Futures of life death on earth. derrida's general ecology. Rowman \& Littlefield, London

Marchart O (2010) Die politische Differenz. Zum Denken des Politischen bei Nancy, Lefort, Badiou, Laclau und Agamben. Suhrkamp Verlag, Berlin

Mitchell T (2009) Carbon democracy. Econ Soc 38:399-432

Muraca B (2010) Denken im Grenzgebiet: Prozessphilosophische Grundlagen einer Theorie starker Nachhaltigkeit. Verlag Karl Alber, Freiburg/München

Norris A (2017) Becoming who we are. politics and practical philosophy in the work of stanley cavell. Oxford University Press, New York

Povinelli E (2016) Geoontologies. A requiem to late liberalism. Duke University Press, Durham

Rosa H (2003) Social acceleration: ethical and political consequences of a desynchronized high-speed society. Constellations 10:3-33

Séville A (2017) "There is no Alternative" Politik zwischen Demokratie und Sachzwang. Campus Verlag, Frankfurt and New York

Swyngedouw E (2014) Depoliticization ('the political'). In: D'Alisa, Demaria and Kallis (eds) Degrowth: a vocabulary for a new era. Routledge, London

Publisher's Note Springer Nature remains neutral with regard to jurisdictional claims in published maps and institutional affiliations. 